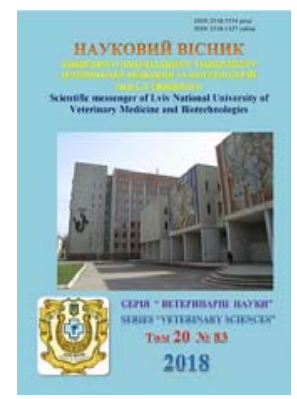

\author{
Науковий вісник Дьвівського національного університету \\ ветеринарної медицини та біотехнологій імені С.3. Гжицького
}

\author{
Scientific Messenger of Lviv National University \\ of Veterinary Medicine and Biotechnologies
}

UDC 619:351.773

\title{
Veterinary aspects of protection people`s heals and role VET departments in the sanitary food safety according to requirements OIE
}

\author{
V.F. Shekel, B.M. Kurtyak, A.I. Padovsky, I.S. Dembitska \\ Stepan Gzhytskyi National University of Veterinary Medicine and Biotechnologies Lviv, Ukraine
}

Article info

Received 08.02.2018

Received in revised form 05.03 .2018

Accepted 12.03.2018

Stepan Gzhytskyi National University of Veterinary Medicine and Biotechnologies Lviv, Pekarska str., 50, Lviv, 79010, Ukraine.

Tel.: +38-032-260-28-89

E-mail:admin@lvet.edu.ua
Shekel, V.F., Kurtyak, B.M., Padovsky, A.I., \& Dembitska, I.S. (2018). Veterinary aspects of protection people's heals and role VET departments in the sanitary food safety according to re-quirements OIE. Scientific Messenger of Lviv National University of Veterinary Medicine and Biotechnologies. 20(83), 357-361. doi: 10.15421/nvlvet8371

The main designs of the creating services of veterinary medicine are struggle with animal diseases and realization a series of obligatory preventive measures to control the most dangerous epizootics. The function services of veterinary medicine spreads to the intermediate chain "from farm - to slaughter» and a complete final chain «from crib - to table». Over the last decades, we have been paying attention to providing food safety from usual methods of control (so-called "good practice») to the using of food safety systems (HACCP). The work of the risk management system is extremely important, it is based on the regulation of the theses of the WTO (World Trade Organization) agreement with the SPM (sanitary and phytosanitary measures). Veterinary services have an important role in the practical implementation of the risk analysis procedure. The tasks set are based on the national legislation of each country, with clear concordance with partners - participants in international trade. In veterinary services tasks includes an important role abreast farms for informing on consultancy on the elimination and control of hazards, including the sanitary safety of feed, residual medicaments and pesticides, mycotoxins and contaminants from the environment. The meat-slaughter inspection of live animals (ante mortem) and their brawns (post mortem) are very important. The Codex for Animal Health contains recommendations for the control of serious biological hazards to animal health and human health by using the above-mentioned inspections. The Codex Alimentarius Commission lead a close cooperation in the preparation of rules that guarantee the protection of food products during the chain of production. The management of the veterinary services have to own the operational systems that allow for the supervision of inspection procedures and the exchange of information in order to achieve maximum effectiveness. Worth integrating systems of animal identification, that make it possible to constantly ascertain the farm of origin as the animals themselves, as well as tracking the processing of slaughter products during the chain. An important function of veterinary services is the issuance of sanitary certificates for both internal use and for export.

Key words: veterinary services, food safety, protection of people, chains «from farm - to slaughterhouse», «from crib - to table».

\section{Ветеринарні аспекти охорони здоров'я населення та роль служб ветеринарної медицини в санітарній безпеці продовольства згідно з вимогами МЕБ}

\author{
В.Ф. Шекель, Б.М. Куртяк, А.І. Падовський, І.С. Дембіцька
}

Львівський національний університет ветеринарної медицини та біотехнологій імені С.3. Гжицького, м. Львів, Україна

Основною метою створення служб ветеринарної медицини є боротьба з хворобами тварин і проведення низки обов'язкових профілактичних заходів для постановки під контроль найнебезпечніших епізоотій. Діяльність служб ветеринарної медицини поширилася на проміжний ланцюжок «від ферми - до бійні» і повний остаточний ланцюжок «від стійла - до столу». За останні десятиліття особливу увагу приділяємо забезпеченню санітарної безпеки продовольства від звиклих методів контролю (так звана 
«належна практика») до застосування систем санітарної безпеки продовольства (НАССР). Надважливою є робота системи управління на основі ризику, вона базується на регламентаџї положеннями угоди СОТ (світова організація торгівлі) з СФС (санітарні й фітосанітарні заходи). Служби ветеринарної медицини відіграють ключову роль у практичному застосуванні процедури аналізу ризику. Поставлені завдання ведуться на основі національного законодавства кожної країни з чітким узгодженням з партнерами - учасниками міжнародної торгівлі. У функції служб ветеринарної медицини входить ключова роль на рівні господарств з інформування в консультування ліквідації та контролю небезпек включно з санітарною безпекою кормів, залишкових медикаментів і пестицидів, мікотоксинів та контамінатів з довкілля. Важливим є м'ясозабійна інспекція живих тварин (апте тогтет) та їх туш (роst mortem). Кодекс здоров'я наземних тварин містить рекомендації з контролю серйозних біологічних небезпек для здоров'я тварин $і$ здоров'я людини за допомогою вищезгаданих інспекиій. Комісія Содех Alimentarius веде тісну співпрацю стосовно підготовки норм, що дозволяють гарантувати захист продукиії харчування по всьому ланиюгу ї̈ виробництва. Керівництво служб ветеринарної медицини зобов'язані володіти операційними системами, цчо дозволяє забезпечити нагляд за інспекційними процедурами та обміном інформацією з метою досягнення максимальної результативності. Варто інтегрувати системи ідентифікаціі тварин, які дають можливість постійно з'ясовувати як господарство походження самих тварин, так $і$ відстежувати переробку продуктів забою по всьому ланџюжку. Важливою функцією служб ветеринарної медицини є видача санітарних сертифікатів як для внутрішнього користування, так і для експорту.

Ключові слова: служби ветеринарної медицини, безпечність продовольства, охорона населення, ланиңюжки «від ферми - до бійні», «від стійла - до столу».

\section{Вступ}

На початках служби ветеринарної медицини були створені для боротьби 3 хворобами продуктивних тварин у господарствах різної форми власності. Основна увага приділялася профілактиці та боротьбі 3 найголовнішими епізоотичними хворобами продуктивних тварин, а також 3 хворобами, що передаються від тварин до людей (зооантропонози). 3 часом, коли вдалося поставити під контроль найнебезпечніші 3 епізоотій, сфера компетенцій служб ветеринарної медицини природно поширилася на хвороби, що впливають на виробництво тваринницької продукції, метою чого стало підвищення продуктивності господарств та поліпшення якості продукції тваринного походження.

Сфера діяльності служб ветеринарної медицини розширилась на ввесь ланцюжок «від ферми - до бійні», в якій лікарі ветмедицини виконують подвійну функцію, забезпечуючи епізоотологічний нагляд за хворобами тварин і санітарну безпеку та дотримання критеріїв якості продукції тваринного походження для споживчих цілей. Володіючи професійною підготовкою як у питаннях хвороб тварин, так і в галузі харчової гігієни, лікарі ветмедицини є найбільш компетентними фахівцями, відіграючи важливу роль у тому, що стосується санітарної безпеки продовольства, насамперед тваринного походження. Крім лікарів ветмедицини, до забезпечення комплексного підходу до санітарної безпеки продовольства впродовж всього ланцюга залучаються працівники інших суміжних професій. В ряді країн компетенції служб ветеринарної медицини були розширені до повного ланцюга «від стійла - до столу».

Максимальні гарантії санітарної безпеки та якості продовольства дає комплексний всебічний підхід, який повністю покриває ланцюжок виробництва харчових продуктів. Ефективність профілактичного підходу полягає в тому, щоб знизити і ліквідувати небажані санітарні ризики порівняно з підходом, що будується виключно на перевірці остаточних продуктів. За останнє десятиліття початкова фаза процесу забезпечення санітарної безпеки продовольства зазнала значних змін: від традиційних методів контролю, що будується на «добрих практиках» (добра сільгосппрак- тика, добра гігієнічна практика), фахівці звернулися до застосування систем санітарної безпеки продовольства, що базуються на аналізі небезпек і на контролі критичних точок (НАССР), прийшовши до методів, що грунтуються на обліку та аналізі ризику для гарантії санітарної безпеки продовольства.

Впровадження систем на основі ризику достатньо обумовлено положеннями Угоди Світової Організації Торгівлі про застосування санітарних та фітосанітарних заходів (угода СФС). За цією Угодою країнипідписанти зобов'язуються свої санітарні та фітосанітарні заходи на оцінці ризиків для життя і здоров'я тварин, людини або рослин, використовуючи методи оцінки ризиків, рекомендовані міжнародними компетентними організаціями. Оцінка ризику, що $є$ науковою підгалуззю аналізу ризику, слід відрізняти від управління ризиками для того, щоб уникнути впливу економічних, політичних i інших інтересів. Угода СФС визнає за нормами, розробленими МЕБ, статус міжнародних довідкових стандартів у сфері здоров'я тварин; норми, розроблені комісією Codex Alimentarius, застосовуються до санітарної безпеки продовольства. Традиційний підхід, згідно 3 яким оператори харчової промисловості зобов'язані гарантувати якість своєї продукції, а санітарна безпека продуктів харчування входить до сфери компетенції агентств зі стандартів, поступово змінюється складнішими схемами, за якими головну відповідальність за якість і санітарну безпеку продуктів, що випускаються на ринок, несуть оператори харчової промисловості. У такому контексті роль органів контролю полягає в аналізі кола компетенцій, наукової інформації, що обгрунтовує стандарти санітарної безпеки продовольства, які застосовані на стадії як переробки, так і до кінцевого виходу продукції, перевірці того, що системи контролю, які використовують оператори промисловості, $є$ належними і валідованими. У разі недотримання прийнятих норм органи контролю домагаються накладення санкцій.

Служби ветеринарної медицини відіграють ключову роль у практичному застосуванні процедури аналізу ризику та виконанні рекомендацій на рівні регламентаційних актів, що стосується ступеня і характеру залучення лікарів ветмедицини і вирішення 
питань санітарної безпеки продовольства протягом виробничого ланцюга.

Країна зобов'язана визначити свої власні завдання у справі захисту здоров'я тварин та охорони здоров'я населення шляхом проведення консультацій із зацікавленими сторонами (тваринниками, виробниками i переробниками продуктів харчування і споживачами) залежно від суспільних, економічних, культурних, політичних і релігійних умов у країні. Виконання поставлених завдань повинно вестися на основі відповідного національного законодавства i супроводжуватися заходами, покликаними привернути увагу як партнерів всередині країни, так і учасників міжнародної торгівлі.

\section{Матеріал і методи досліджень}

Служби ветеринарної медицини вносять значний вклад, забезпечуючи аудит діяльності щодо здоров'я тварин та охорони здоров'я людини, відповідальність за ведення якого покладено на інші офіційні служби, приватно практикуючих лікарів ветмедицини та інших задіяних партнерів. Крім лікарів, до числа фахівців, які залучаються до роботи на тій чи іншій ділянці харчового ланцюга, входять: аналітики, епідеміологи, епізоотологи, техніки харчової промисловості, експерти зі здоров'я людини, екологи, мікробіологи і токсикологи. Яким би не був розподіл ролей між цими та іншими фахівцями в адміністративній системі різних країн, слід домагатися підтримки тісної співпраці та постійної комунікації між ними для досягнення найкращих результатів. У результаті залучення лікарів ветмедицини і фахівців або звернення до послуг організацій, які не підпорядковані службам ветеринарної медицини, вимагається забезпечити їх точними технічними вимогами, що містять регламентні норми системи перевірки ефективності, яка дозволяє вести моніторинг і контроль роботи зовнішніх підрядників. Кінцева відповідальність за належне проведення робіт, довірених зовнішнім підрядникам, покладається на керівництво служб ветеринарної медицини.

Самою присутністю в господарствах і підтримкою, яку служби ветмедицини надають тваринникам, забезпечується ключова функція: перевірка того, що тварини утримуються в належних гігієнічних умовах, раннє виявлення та лікування хвороб, у т. ч. хвороб, що впливають на здоров'я людей. Служби ветмедицини надають тваринникам послуги з інформування, консультування та навчання з метою контролю, недопущення ліквідації та небезпек, що загрожують санітарній безпеці продовольства та кормів на етапі виробництва (залишкові медикаменти і пестициди, мікотоксини і контамінанти 3 навколишнього середовища). Тваринницькі асоціації, особливо в тому випадку, коли вони користуються консультаційними послугами лікарів ветмедицини, є найбільш ефективними організаціями для інформування та навчання, будучи в постійному контакті 3 тваринниками і найкраще розуміючи їх потреби. Технічна допомога, що надається службами ветмедицини приватнопрактикуючим лікарям і керівництву установ ветеринарної медицини має основоположне значення. Слу- жби ветмедицини відіграють важливу роль, сприяючи відповідальному й обережному використанні біопродуктів і ветмедикаментів у господарствах в т.ч. антимікробних продуктів. Тим самим вони вносять вклад у зниження ризику розвитку антибіорезистентності та підтримку рівня залишкових медикаментозних речовин у продовольстві тваринного походження нижче допустимих порогів. У відповідних розділах Кодексу здоров'я наземних тварин містяться рекомендації щодо використання антимікробних речовин у ветмедицини.

\section{Результати та їх обговорення}

М'ясозабійна інспекція живих тварин (передзабійна) та їх туш (післязабійна) - важлива ланка мережі нагляду за хворобами тварин і зооантропонозами $\epsilon$ гарантією безпечності м'яса і м'ясної продукції 3 урахуванням їх кінцевого призначення. Контроль i зменшення біологічних небезпек, що позначаються на

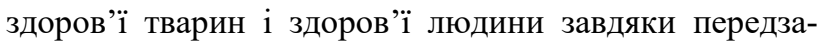
бійній і післязабійній інспекції - одне 3 основних завдань служб ветмедицини, зобов'язаних стежити, щоб на місцях реалізовувалися відповідні програми. В міру можливості інспекційні процедури повинні будуватися на ризику. Системи управління мають враховувати міжнародні норми і бути спрямовані на найбільш серйозні небезпеки для здоров'я тварин і здоров'я людини. Практичний кодекс з гігієни м'яса, створений Codex Alimentarius - головний міжнародний нормативний документ в даній галузі. Він заснований на підході, що базується на ризиках при прийнятті санітарних заходів на кожній ділянці м'ясного ланцюжка. У відповідних статтях Наземного кодексу містяться рекомендації з контролю серйозних біонебезпек для здоров'я тварин і людини за допомогою передзабійних і післязабійних інспекцій. Історично склалося, що пріоритетом з Наземного кодексу є захист здоров'я тварин на планеті та забезпечення відкритості цієї діяльності. МЕБ згідно з мандатом також займається ризиками, пов'язаними з санітарною безпекою продовольства тваринного походження на етапі виробництва. У Наземний кодекс включено комплекс норм і рекомендацій, створених для здоров'я людини, поряд з цим іде процес розробки нових норм 3 метою попередження контамінації продуктів тваринного походження Salmonella spp. i Campylobacter spp. МЕБ та Комісія Codex Alimentarius ведуть тісну співпрацю у справі підготовки норм, що дозволяють гарантувати захист продуктів харчування по всьому ланцюгу їхнього виробництва. Що стосується виробництва та санітарної безпечності продуктів тваринного походження, рекомендації МЕБ повинні читатися паралельно з рекомендаціями Комісії Codex Alimentarius. Керівництво ветеринарних служб зобов'язане допускати певну свободу маневрування в ділянці послуг з інспекції м'яса. Країни мають можливість вибору з числа різних моделей управління 3 різним ступенем делегування функцій офіційним організаціям, що діють під контролем і егідою керівництва служб ветеринарної медицини. У разі залучення приватних партнерів до проведення передза- 
бійних і післязабійних інспекцій під загальним керівництвом і відповідальністю служб ветмедицини, вони зобов'язані уточнити набір компетенцій у кожному конкретному випадку i проконтролювати належне виконання завдань, поставлених перед зовнішніми підрядниками. Керівництво служб ветмедицини зобов'язане володіти операційними системами, що дозволяє забезпечити нагляд за інспекційними передзабійними і післязабійними процедурами та обмін інформацією, щоб домогтися їх більшої результативності. Слід інтегрувати системи ідентифікації тварин і відстеження, які дають можливість з'ясувати господарство походження забійних тварин і простежити, в які заклади надійде на переробку продукція забою по всьому м'ясному ланцюжку.

Сертифікація продукції тваринного походження для цілей ветеринарної торгівлі є однією з функцій служб ветмедицини з видачею сертифікатів для торгових партнерів 3 метою гарантії, що експортована продукція відповідає стандартам здоров'я тварин і санітарної безпеки продовольства. Сертифікація відсутності хвороб тварин, в т.ч. зооантропонозів, а також гігієнічних стандартів м'яса входить до сфери компетенції керівництва служб ветмедицини. Деякі сертифікати можуть видаватися фахівцями інших професій, що залучені до процесу переробки та упаковки (пастеризація молокопродуктів), і підтверджувати відповідність продукції нормам якості.

Велика частина спалахів харчових токсикоінфекцій викликані контамінацією продовольства збудниками зооантропонозів на первинному етапі виробництва. Одним з важливих завдань служб ветмедицини є проведення розслідування цих спалахів шляхом виявлення господарства походження, а після ідентифікації джерела зараження - планування і накладання належних корегуючи заходів. Ці завдання повинні вирішуватися в тісній співпраці з фахівцями у сфері здоров’я людини: екологами, аналітиками, епідеміологами, епізоотологами, виробниками та переробниками, торгівлею та іншими партнерами. Крім функцій, що ми описали вище, на лікарів ветмедицини покладається виконання завдань, пов'язаних з санітарною безпекою продовольства на різних ділянках харчового ланцюга, зокрема контроль на основі принципів НАССР або інших систем гарантії якості в процесі переробки та дистрибуції продовольства. Служби ветмедицини також відіграють важливу роль у питаннях залучення уваги виробників, переробників та інших зацікавлених сторін до обов'язкових заходів з гарантії санітарної безпеки продовольства.

Щоб домогтися максимальної віддачі від діяльності служб ветмедицини у області санітарної безпеки продовольства, особливо важливе проходження лікарями ветмедицини базового навчання та курсів підвищення кваліфікації і професійного рівня, 3 цією метою повинні діяти державні програми. Служби ветмедицини мають можливість ознайомитися з основними принципами якості,що описані у відповідній главі наземного кодексу і з Інструментом МЕБ оцінки ефективності служб ветмедицини. Ланцюжок віддачі розпоряджень, як і розподіл відповідальності всередині служб ветмедицини, повинні бути чітко опрацьо- вані та ретельно задокументовані. Компетентний орган країни зобов'язаний забезпечити служби ветмедицини легальними рамками, що дозволяють розробляти і проводити в життя політику із забезпеченням іiі ресурсами, достатніми для ефективного і безперервного виконання належних функцій. В ході розробки проведення політики та програм санітарної безпеки продовольства керівництво служб ветмедицини повинно діяти в тісному співробітництві з іншими компетентними органами для гарантії того, що ризикам, пов'язаних із санітарною безпекою продуктів харчування, приділяється найсерйозніша увага.

Загальновизнано, що хвороби і зооантропонози, які передаються через харчові продукти, являють собою важливу проблему суспільної охорони здоров'я і одну з причин зниження економічної продуктивності як у розвинених країнах, так і в тих, що розвиваються. Поширення серйозних небезпек для здоров'я тварин через ланцюжок виробництва м'яса i м'ясних субпродуктів здатне викликати значні економічні втрати у тваринницькій галузі. Інспекція забійних тварин може стати важливою підмогою нагляду за низкою хвороб, які позначаються на здоров’ї тварин і людини. Ліквідація та зниження рівня біологічної небезпеки для здоров'я тварин і людей шляхом проведення до- і післязабійної інспекції входить до основних обов'язків служб ветеринарної медицини.

У актуальних рекомендаціях міститься база для перспективної розробки стандартів МЕБ щодо санітарної безпеки продукції тваринного походження на етапі виробництва. Кодекс належних практик з гігієни м'яса (CHРM), виданих Codex Alimentarius, являє собою основний комплекс міжнародних стандартів, що стосуються гігієни м'яса. Цей документ будується на основі підходу, що враховує ризики, з метою виконання санітарних заходів на всіх етапах ланцюжка виробництва м'яса. Передзабійна інспекція описана в ньому як основна складова гігієни м'яса перед забоєм а післязабійна інспекція - як основний елемент контрольних процедур, пов'язаних з гігієною м'яса після забою. СНРМ окремо визнає подвійну спрямованість діяльності, що проводиться інспекційними службами на бойнях, не включає інспекційних заходів, що стосуються специфічних небезпек, оскільки такі заходи відносять до компетенції державної влади кожної країни. Ризики для здоров'я тварин i людини, пов'язані з популяціями домашніх тварин, зв'язані 3 регіональністю і системами вирощування. До- і післязабійні інспекції повинні бути адаптовані до конкретної ситуації в країні та завдань з питань охорони здоров'я тварин і людини. СНРМ містить платформу розвитку систем гігієни м'яса, що базуються на оцінці ризиків. $€$ невелика кількість моделей оцінки ризиків і наукової інформації, придатної до використання в питаннях небезпеки для здоров'я людини, пов'язаних 3 тваринництвом чи продукцією тваринництва, в результаті чого виникають складнощі при розробці стандартів на основі ризиків щодо хвороб і зооантропонозів, що передаються через харчові продукти. В очікуванні формування комплексу наукових даних системи до- і післязабійної інспекції орієнтуємось на традиційні підходи. Служби ветеринарної медицини 
несуть головну відповідальність за створення програм до- і післязабійної інспекції м'яса. Коли це можливо на практиці, процедури інспекції повинні грунтуватися на ризиках, а системи управління мають відповідати міжнародним стандартам і покривати всі найбільші небезпеки для здоров'я тварин і людини, пов'язані $з$ забоєм тварин. У питаннях до- і післязабійної інспекції відповідальність служб ветеринарної медицини включає:

1. Оцінку та управління ризиками;

2. Розробку політики і стандартів ;

3. Концепцію і управління програмами інспекції;

4. Перевірку та сертифікацію адекватності інспекційної діяльності та ііі належне виконання;

5. Поширення інформації по всьому ланцюжку виробництва м'яса.

Служби ветеринарної медицини, коли це можливо на практиці, повинні звертатися до оцінки ризиків при розробці санітарних заходів. Вони мають віддавати пріоритет аналізу мікробного зараження, приділяючи увагу виявленню макроскопічних аномалій в ході доі після забійного огляду, оскільки саме ця контамінація являє собою основне джерело небезпек.

Мікробіологічне, серологічне тестування та інші практики (як індивідуальне дослідження, так і стадне ) в рамках до- і післязабійної інспекції повинні використовуватися для доповнення нагляду та оцінки ризику передачі харчових небезпек, причому робота за цими аспектами має вестися з урахуванням іï значущості. Централізовані дані повинні бути пов'язані $з$ даними про хвороби людини, що дозволить оцінити ефективність різних опцій управління ризиками та провести загальну оцінку походження хвороб, що передаються через харчові продукти.

Дотримання загального формату має на увазі регулярну і узгоджену процедуру для управління всіма ризиками в питаннях біобезпеки з використаннями різних методик оцінки ризиків, які застосовуються щодо здоров'я тварин і охорони здоров'я людини.

Органи державної влади зобов'язані підготувати відповідну юридичну базу, щоб дозволити службам ветмедицини провести розробку політики і стандартів. Вона повинна не тільки відповідати завданням охорони здоров'я людей, а також мати на меті виявлення і ліквідацію небезпек по всьому ланцюжку виробництва м'яса. Одним з рішень може бути знищення живих тварин за результатами дозабійної інспекції або знищення продукції за результатами післязабійної інспекції. Служби ветеринарної медицини, коли це можливо на практиці, повинні ретельно регулювати свою діяльність (наприклад в питаннях процедур міжнародної сертифікації) 3 тим, щоб уникати прийняття дублюючих і високовитратних рішень.

У справі охорони здоров'я тварин і людини, згідно з державними законодавствами, або для відповідності вимогам країни-імпортера служби ветеринарної ме- дицини можуть діяти безпосередньо, беручи на себе виконання функцій ветеринарної медицини, або виступати в ролі аудитора діяльності інших органів чи приватного сектору, якому довірені питання здоров'я тварин та людини. Для цього служби ветеринарної медицини зобов'язані надавати гарантії відповідності діючим стандартам безпеки як у країні, так і у взаєминах із закордонними торговельними партнерами. Служби ветеринарної медицини повинні виявляти гнучкість у питаннях інспекції м'яса, вдаючись до послуг офіційно визнаного компетентного органу, що перебуває під їх наглядом i контролем. Визнаючи зацікавленість промисловості в питаннях безпечності продовольства і питаннях до- і післязабійної інспекції допускається доповнення систем гарантії якості служб ветеринарної медицини системами, що діють у промисловості. При цьому служби ветмедицини повинні враховувати фактори оцінки самих служб ветмедицини. Проте, коли працівник приватного сектору залучаються для проведення до- і післязабійної інспекції під наглядом і спільною відповідальністю служб ветеринарної медицини, останні зобов'язані чітко визначити рівень компетентності, якому повинні відповідати залучувальні працівники і пересвідчитися у високій кваліфікаційній якості їх роботи.

\section{Висновки}

Забезпечення та сертифікація точної відповідності інспекційної діяльності легальним положенням є найважливішою функцією служб ветеринарної медицини. Міжнародні санітарні сертифікати, що містять офіційні гарантії з торгівлі м'ясом, повинні викликати повну довіру в країнах-імпортерах. Підготовка та поширення інформації про весь ланцюжок виробництва м'яса є багатопредметним завданням. Для забезпечення ефективного проведення процедур до- і післязабійної інспекції служби ветеринарної медицини повинні впровадити системи нагляду за цими процедурами та інформування про них. Також має бути програма моніторингу небезпек у критичних ланках ланцюжка виробництва м'яса для того, щоб полегшити оцінку ефективності проведеного контролю. Повинні діяти системи ідентифікації та відстеження тварин, що дозволяють по всьому харчовому ланцюжку пов'язувати забійних тварин $з$ місцем їх походження та продукцією, що з них отримана на конкретних переробних підприємствах.

\section{References}

1. Kodeks zdorov'ja nazemnyh zhivotnyh MJeB (2014). Dvadcat' tret'e izdanie. ISBN: 978-92-9044-960-7 (in Russian). 